\title{
MASJID TUA ALMUJAHIDIN WATAMPONE (Sejarah Pendiriaan dan Fungsinya : kaintannya dengan pendidikan islam)
}

\author{
Ridhwan \\ Sekolah Tinggi Agama Islam Negeri Watampone, Bone, Indonesia \\ e-mail: ridhwandr@gmail.com
}

\begin{abstract}
This article discusses the standing history and function of the Almujahidin Watampone Old Mosque in Bone Regency. The results of the study show that the Almujahidin Old Mosque was founded by Fakih Amrullah around 1632 AD. He is Kadhi pertma in the Kingdom of Bone. The construction of the Almujahidin Mosque was intended for the royal family of Bone, as well as a place for implementing and fostering Islamic education. Before the kingdom of Bone integrated with the Indonesian Unitary State, the Kadhi of the Kingdom of Bone made the Old Mosque of Almujahidin their place of activity. Its function as a place of education continues, although Bone is no longer the Kingdom.
\end{abstract}

Keywords: Masjid Almujahidin, fungsi social, sejarah pendidikan

\section{Pendahuluan}

Barangkali bukanlah suatu kebetulan jika dalam peristiwa hijrah, sebelum Nabi Muhammad sampai di Yastrib, ia bersama kaum Muhajirin1 lainnya singgah di desa Quba, selama empat hari. Di tempat ini Nabi mendirikan sebuah masjid yang hingga saat ini dikenang sebagai Masjid Quba. Demikian juga ketika Nabi sampai di Kota Yastrib (kelak menjadi kota Madinah), ia membangun sebuah masjid yang kelak dikenang sebagai Masjid Nabawi. ${ }^{2}$ Demikian juga dalam perjalanan Isra' dan Mi'raj Nabi Muhammad, yang diyakini oleh kalangan pengamal sufi sebagai prototipe pengalaman ketuhanan seorang muslim sejati ${ }^{3}$, juga tak lepas dari masjid, yakni ketika Nabi berangkat dari

\footnotetext{
${ }^{1}$ Istilah kaum Muhajirin sering disandingkan dengan kaum Anshar. Kaum Muhajirin mengacu kepada kaum muslimin Mekah yang ikut bersama Nabi Muhammad hijrah ke Madinah. Sedangkan kaum Anshar mengacu kepada kaum muslimin Madinah yang menyambut dan menolong kedatangan Nabi Muhammad ketika hijrah.

${ }^{2}$ Uraian lebih lengkap tentang profil Masjid Nabawi (Masjid Nabi) dapat dibaca dalam Zuhairi Misrawi, Madinah; Kota Suci, Piagam Madinah, dan Teladan Muhammad Saw., (Jakarta: PT. Kompas Media Nusantara, 2009), h. 331-384.

${ }^{3}$ Salah seorang sufi yang paling senang menggambarkan perjalanan Isra' dan Mi'raj sebagai simbolisme pengalaman ketuhanan seorang muslim adalah Maulana Jalaluddin Rumi (1207-1273 M). Dalam hal ini John Renard mengatakan bahwa: "Rumi telah menggunakan istilah itu (Mi'raj) untuk secara paradoks memberi hakikat abadi pengalaman seorang individu tentang Tuhan". Lihat John Renard "All The King's Falcon; Rumi On Prophets and Revelation”, diterjemahkan oleh Muhammad Hasyim Assagaf, Rajali Sang Raja; Senandung Rumi Tentang Nabi dan Wahyu, (Cetakan pertama; Jakarta: PT. Serambi Ilmu Semesta, 2001), h. 223. Seorang Sufi Besar Abad ke-13, Fariruddin al-
} 
Masjid Haram di Mekkah ${ }^{4}$ menuju Masjid al-Aqsha di Palestina. ${ }^{5}$ Hal tersebut menunjukkan bahwa seorang muslim hendaknya menjadikan masjid sebagai sarana gerakan sosial menuju penyempurnaan spiritual.

Pada masa-masa selanjutnya, masjid menjadi perhatian utama. Para sahabat yang menjadi khalifah setelah wafatnya Nabi Muhammad juga tak kalah besar perhatiannya terhadap masjid. Abu Bakar al-Shiddiq (khalifah pertama) menjadikan Masjid Nabawi sebagai tempat berlangsungnya pemerintahan, di samping fungsi-fungsi peribadatan yang telah berlangsung sejak didirikan pada masa Rasulullah. Demikian Umar bin al-Khaththab, ketika menjadi khalifah menggantikan Abu Bakar diketahui merenovasi Masjid Haram, Hal paling fenomenal dalam sejarah terkait dengan Umar bin Khathth abadalah ketika mendirikan sebuah masjid ${ }^{6}$ di samping gereja pada saat kaum muslimin merebut kota suci Yerussalem atau Bait al-Maqdis (Rumah Suci). ${ }^{7}$

Dalam konteks sejarah pendidikan Islam, terdapat indikasi kuat bahwa masjid menjadi basis utama. Bahkan dapat dikatakan bahwa lembaga pendidikan pertama dan utama pada masa Islam klasik adalah masjid. ${ }^{8}$ Masjid menjadi semacam katalisator dan gerbong utama dalam upaya islamisasi di sebuah wilayah yang baru memeluk Islam. Selain itu, masjid kelihatannya sudah menjadi ikon dan bukti kehebatan, bahkan merupakan kebanggaan tersendiri bagi para penguasa Islam di sepanjang sejarah sosial umat Islam. ${ }^{9}$

Aththar, menyebut perjalanan Isra' Mi'raj Nabi Muhammad tersebut sebagai contoh riil dari konsep fana dan baqa. Mi'raj menjadi sebuah paradigma penyatuan mistik dengan Tuhan, yakni kefanaan dalam Tuhan yang diiukuti oleh kehadiran (baqa) dan kesadaran diri yang semakin tinggi. Lihat Karena Amstrong "Muhammad; A Biografi of Prophet" diterjemahkan oleh Sirikit Syah, Muhammad Sang Nabi; Sebuah Biografi Kritis, (Cetakan pertama; Surabaya: Risalah Gusti, 2001), h. 189-190.

${ }^{4}$ Uraian lebih lengkap tentang profil Masjid Haram di Mekah dapat dibaca dalam Zuhairi Misrawi, Mekkah; Kota Suci, Kekuasaan, dan Teladan Ibrahim, (Jakarta: PT. Media Kompas Nusantara, 2009), h. 191-212.

${ }^{5}$ Uraian singkat namun menarik tentang Masjid al-Aqsha dapat dibaca dalam Nurcholish Madjid, Pintu-Pintu Menuju Tuhan, (Cetakan IV; Jakarta: Paramadina, 2002), h. 74. 79.

${ }^{6}$ Masjid yang dibangun Khalifah Umar di sampng gereja di kota Yerussalem kemudian dikenal dengan nama Masjid Umar. Pada masa Bani Umayyah, masjid ini direnovasi oleh Khalifah Abdul Malik Bin Marwan. Masjid ini juga dikenal dalam istilah Arab "Qubbat al-Sakhrah". Dalam istilah Barat dikenal dengan The Dom of the Rock, "Masjid Batu Karang". Pembahasan menarik tentang hal ini dapat dibaca dalam Umar Amin Hoesin, Kultur Islam, (Jakarta: Bulan Bintang, 1982), h. 127. Bandingkan dengan Ira M. Lapidus, "A History of Islamic Socienties" diterjemahkan oleh Ghufron A. Mas'adi, Sejarah Sosial Umat Islam, Jilid I dan II (Cet. I; Jakarta: RajaGrafindo Persada, 1999), h. 131.

${ }^{7}$ Uraian lebih rinci mengenai Kota Suci Yerusalem atau Bait al-Maqdis dapat dibaca dalam Trias Kuncahyono, Jerussalem; Kesucian, Konflik, dan Pengadilan Terakhir, (Cetakan pertama; Jakarta: PT. Media Kompas Nusantara, 2008), h. 247-254.

${ }^{8}$ Lihat Azsyumardi Azra, Pendidikan Islam; Tradisi dan Modernisasi Menuju Melinium Baru, (Cetakan I; Jakarta: PT Logos Wacana Ilmu, 1999), h. vii. Bandingkan dengan George Abraham Makdisi "The Rise of Humanism in Classical Islam and The Christian West" diterjemahkan ke dalam bahasa Indonesia oleh A. Syamsurizal dan Nurhidayah, Cita Humanisme Islam; Panorama Kebangkitan Intelektual dan Budaya Islam dan Pengaruhnya Terhadap Renaissance Barat, (Jakarta: PT. Serambi Ilmu Semesta, 2007), h. 89-93.

${ }^{9}$ Lihat Ira M. Lapidus, "A History of Islamic Socienties" diterjemahkan oleh Ghufron A. Mas'adi, Sejarah Sosial Umat Islam, Jilid I dan II, h.131. 
Oleh karena itu, para ahli sejarah, baik muslim maupun para orientalis Barat menjadikan masjid sebagai objek kajian yang tak kalah menariknya, selain objek-objek lainnya. Seorang orientalis sekelas Ernest Renan yang dikenal kurang ramah terhadap Islam, sampai-sampai harus mengakui akan hal ini. Salah satu ucapannya yang terkenal menyebutkan bahwa: "Je ne suis jamais entre' dans une mosquee' sans une vive emotion", artinya: "Saya tidak pernah masuk ke sebuah masjid, tanpa suatu emosi yang timbul".10

\section{Sejarah Pendirian Masjid Al-Mujahidin}

Masjid Al-Mujahidin Watampone, dikenal juga dengan nama Masigi Laungnge (Bugis) atau Masjid Tua. Diyakini oleh banyak kalangan di Bone bahwa masjid inilah yang pertama dibangun di Bone.11 Tidak ditemukan catatan yang jelas mengenai tanggal dan tahun berdirinya. Namun demikian, dalam catatan Asnawi Sulaiman, disebutkan bahwa Masjid Al-Mujahidin didirkan oleh Kadhi Kerajaan Bone yang pertama, Fakih Amrullah, sesat setelah menjadi Kadhi di Kerajaan Bone di lingkungan istana Kerajaan Bone. ${ }^{12}$

Langkah pertama yang dilakukan oleh Faqih Amrullah sebagai kadi di Kerajaan Bone adalah membangun sebuah masjid di dekat istana Kerajaan Bone. Di masjid inilah Patta Kalie pertama memberikan bimbingan dan pengajaran kepada keluarga istana Bone. ${ }^{13}$

Penting ditegaskan bahwa Fakih Amrullah bukanlah orang Bone, melainkan orang Gowa. Faqih Amrullah lahir di Gowa sekitar tahun 1603 M. Dari pihak ayah, ia adalah putra seorang keturunan Arab, Sayid Muhsin. Sayid Muhsin sendiri adalah putra dari Sayid Ba'Alwi bin Abdullah, seorang ulama yang datang dari Mekah dan menetap di Kerajaan Gowa tidak lama setelah Gowa menerima Islam. ${ }^{14}$ Ibunya adalah putri I Malingkaan Daeng Manyonri Sultan Abdullah Awwalul Islam (Raja Tallo) dan Mangkubumi Kerajaan Gowa, Raja Tallo yang pertama masuk Islam. ${ }^{15}$ Dengan demikian, dari jalur ibu ia adalah keluarga bangsawan Gowa.

Asnawi Sulaiman menyebutkan bahwa bahwa kadi pertama di Kerajaan Bone tidak diangkat oleh Raja Bone sebagaimana lazim pada pengangkatan Kadi Bone berikutnya, tetapi ia dikirim oleh Raja Gowa ke-15, Sultan Malikussaid

\footnotetext{
${ }^{10}$ Lihat G.F. Pijper "Studien over de geschiedenis van de Islam in Indonesia 1900-1950", diterjemahkan oleh Tudjimah dan Yessi Augustin, Beberapa Studi Tentang Sejarah Islam di Indonesia 1900-1950, (Cet Kedua; Jakarta: UI-Press, 1986), h 14.

${ }^{11}$ Mahyuddin. Ketua Pengurus Masjid al-Mujahidin, Wawancara, Watampone, 2 November 2017.

${ }^{12}$ Lihat Asnawi Sulaiman, Sejarah Singkat Keqadhian (Qadhi) Bone (Cetakan I; Jakarta: Lembaga Solidaritas Islam al-Qashash), 2004, h. 14

${ }^{13}$ Lihat Asnawi Sulaiman, Sejarah Singkat Keqadhian (Qadhi) Bone, h. 14.

${ }^{14}$ http://www.tribun-timur.com/read/artikel/49050 Cetak Panrita Dari Bontoala, Salemo, Hingga Mangkoso, Kamis, 17 September 2009| 15:58 WITA, diakses pada tanggal 5 Juni 2012.

${ }^{15}$ Lontara Pattorioloonga ri Gowa dikutip dariAsnawi Sulaiman, Sejarah Singkat Singkat Keqadhian (Qadhi) Bone, h. 14.
} 
(1639-1653 M). Asnawi Sulaiman tidak menyebutkan secara jelas angka tahun pengiriman Fakih Amrullah sebagai kadi di Kerajaan Bone. Ia hanya menyebutkan bahwa pengiriman tersebut terjadi pada masa pemerintahan Raja Bone ke-13 La Ma'daremmeng Sultan Muhammad Shalih Matinroe ri Bukaka $(1632-1640 \mathrm{M}){ }^{16}$

Untuk memperkirakan tahun pengiriman Fakih Amrullah menjadi kadi yang sekaligus menandai awal pembangunan Masjid al-Mujahidin, dapat dilakukan dengan membanding antara masa pemerintahan Raja Gowa Sultan Malikussaid dan Raja Bone La Ma'daremmeng Sultan Muhammad Shalih. Raja Gowa ke-15, Sultan Malikussaid, memerintah antara tahun 1639 sampai1653 M,17 sedangkan La Ma'daremmeng memerintah antara tahun 1632 sampai 1640.18 Dengan demikian, dapat disimpulkan bahwa pengiriman Fakih Amrullah tersebut diperkirakan terjadi pada tahun pertama pemerintahan Raja Gowa Sultan Malikussaid (1639 M) yang bertepatan dengan akhir masa pemerintahan Raja Bone Lama'daremmeng Sultan Muhammad Shalih, yakni paroh pertama tahun $1640 \mathrm{M}){ }^{19}$

Jika kesimpulan di atas benar, maka dapat diperkirakan bahwa tahun berdirinya Masjid al-Mujahidin adalah sekitar tahun 1639 M yang bertepatan dengan masa-masa berakhirnya pemerintahan Raja Bone Lama'daremmeng Sultan Muhammad Shalih Matinroe ri Bukaka (1632-1640 M).

\section{Fungsi}

Dalam penelusuran penulis pemanfataan atau fungsi Masjid alMujahidin, kelihatannya tidak jauh berbada denngan fungsi masjid sebagaimana yang berlaku sejak zaman Nabi sampai masa-masa berikutnya, yakni fungsi ibadah dan fungsi sosial. Berikut penjelasannya:

Fungsi Ibadah

Dapat dipastikan bahwa keberadaan Masjid al-Mujahidin, sejak didirikan oleh Kadhi Bone Pertama, Fakih Amrullah bin Saiyyid Muhsin bin Sayyid Ba'alwi Abdullah adalah agar dapat berfungsi sebagai tempat ibadah. Ibadah yang dimaksud di sisi adalah ibadah-ibadah mahdha, misalanya, shalat, dzikir, berdoa, I'tikaf dan lainya. Pelaksanaan Ibadah tersebut terutama diperuntukkan kepada Raja dan bangsawan istana kerajaan Bone lainnya.

Fungsi Pendidikan

Secara umum sangat sedikit catatan semasa yang menggambarkan pelaksaan pendidikan Islam pada masa-masa awal. Meskipun demikian, seorang

\footnotetext{
${ }^{16}$ Lihat Asnawi Sulaiman, Sejarah Singkat Keqadhian (Qadhi) Bone, h. 14.

${ }^{17}$ Lihat Leonard Y. Andaya, The Heritage of Arung Palakka; A History of South Sulawesi (Celebes) In the Sevententh Century (Warisan Arung Palakka: Sejarah Sulawesi Selatan Abad ke-17, h. 381.

${ }^{18}$ Mattulada. LATOA: Satu Lukisan Analitis Terhadap Antropologi Politik Orang Bugis. Cet. II; Ujung Pandang: Hasanuddin University Press, 1995 h. 76.

${ }^{19}$ Lihat Asnawi Sulaiman Sejarah Singkat Keqadhian (Qadhi) Bone, h 24.
} 
pengamat Prancis bernama Gervaise meninggalkan catatan penting tentang pendidikan anak-anak bangsawan di Istana Gowa abak ke-17. Ia menulis:

Sesudah anak laki-laki berumur 5 atau 6 tahun, mereka lazim disuruh didik pada orang lain untuk mencegah pengaruh ibunya yang dapat mengakibatkan melemahnya sifat kejantanannya. Kalau mereka sudah berumur 7 atau 8 tahun mereka mulai belajar mengaji, menulis dan berhitung di bawah pimpinan seorang "Haji", satu jam pagi dan satu jam sore, selama dua tahun....20

Penulis menduga kuat bahwa pola pendidikan yang berlaku di Gowa sebagaimana tergambar dalam kutipan di atas juga berlaku di Kerajaan Bone. Hal ini didasarkan pada keteragangan sebelumnya bahwa orang yang bertama melaksanakan pendidikan Islam secara resmi di Kabupaten Bone adalah Kadhi pertama Bone, Fakih Amrullah, yang berasal dari Gowa.

Berkaitan dengan pembinaan pendidikan Islam di Masjid Al-Mujahidin, sampai awal abad ke-19 tidak ditemukan gambarannya secara rinci, misalnya tentang materi dan kitab-kitab yang dibaca dan lain-lain. Namun dapat diyakini bahwa sejak ditetapkannya Islam sebagai agama resmi Kerajaan Bone pendidikan Islam berupa pengajian-pengajian Al-Qur'an dan kitab kuning (mangaji kitta) sudah berlangsung.

Di era Raja Bone Arung Palakka (1667-1696 M) misalnya diyakini bahwa ketika itu pengajian Al-Qur'an dan kitab kuning tumbuh pesat, sebab Arung Palakka sendiri yang memberikan perintah. Dalam salah satu pidatonya tidak lama setelah dinobatkan menjadi Raja Bone, dalam acara pemotongan rambut Arung Palakka sebagaimana janjinya jika dapat mengalahkan Gowa tahun $1670 \mathrm{M}$, ia mengatakan:

“...mau silellang mua bola nalimpungi awo', napobicarai bicaranna, naiya nabbicarang nasengnge palorongngi welerenna, paddaungi raukkajunna, napoarajangngi Bone napoadecengngi palili'na, napoatuangngi tomaegae. Tapada letei petautta pelempu' togi mejekko togi. Tapada poanui akkeanung toriolota de'eppa bicara lawangngi. Naiya taola gau'na Puatta Matinroe ri Gucinna sangngadinna riakaperekenna. Iyatopa mennang ripoadakko, mau silelleng mua bola nalipungi awo', pada patettokko langkara', tapeasseriwi agamae. Iyatopa mennang ripallebbariakko palili' simemengennae Bone, rekko engkai suro ribatennae Bone muttama' riwanuammu maelo' marala, aja' mualai, iayanatu napoarajang Bone. Narekko tassinrupai ada ripattenningangngekko arolano risurona Bone mulattu poadai ri Bonemu, tennalai tu Bonemu nakko tennapasilasai...

Terjemahnya:

\footnotetext{
${ }^{20}$ Lihat Andi Zainal Abidin Farid, Persepsi Orang Bugis Makssar Tentang Hukum Negara dan Dunia Luar. Badung: Alumni, 1983), h. 36.
} 
“...walaupun hanya sebuah keluarga/rumah berpagar bambu, tetap diakui haknya untuk melaksanakan hukum adat yang dapat memelihara hubungan baik dan membesarkan kerajaan Bone demi kebaikan rakyat. Tetap berpegang teguh kepada hukum adat dan mengakui hak milik perorangan yang telah berlangsung sejak dahulu. Tetap berpegang teguh kepada peraturan "panngaderreng" yang telah ditetapkan oleh Puatta' La Tenrirawe, Bonkangnge, Matinroe ri Gucinna (Raja Bone ke-7) kecuali kekafirannya. Selanjutnya, walaupun hanya sebuah keluarga/rumah yang berpagar bambu, agar didirikan langgar/masjid guna meneguhkan pelaksanaan syari'at agama Islam. selanjutnya, diumumkan, apa bila ada utusan pribadi raja Bone memasuki daerah untuk mengambil seseorang/sesuatu, jangan sekali-kali dihalangi. Itulah salah satu kebesaran Bone. Apa bila tindakan mereka bertentangan dengan adat yang berlaku, ikutilah mereka untuk menghadap raja Bone. Raja Bone tidak akan mengambil sesuatu dari kalian apabila tidak sesuai dengan hukum yang berlaku yang berdasarkan panngaderreng...21

Dalam pidato tersebut, Arung Palakka jelas menyerukan kepada seluruh rakyat Bone untuk membangun langkara atau langgar (surau) di setiap kampung, agar masyarakat dapat menperdalam ilmu agama Islam. Hal ini juga menunjukkan bahwa upaya islamisasi di Kerajaan Bone melalui pendidikan Islam terus berjalan.

Khusus di Masjid al-Mujahidin Asnawi Sulaiman menyebutkan bahwa setelah dibangun sekitar tahun 1639 M, Faqih Amrullah melaksanakan pendidikan dan pengkaderan bagi para juru dakwah dalam upaya pengembangan dakwah Islam di Kerajaan Bone. Salah seorang kader atau murid yang juga putranya sendiri adalah Syekh Ismail yang kelak menggantikannya sebagai Kadi Bone ke-4.22Proses pendidikan Islam yang dilaksanakan di Masjid Al-Mujahidin terus berlangsung, dan para Kadi Bone menjadi tokoh utamanya. Model pembelajaran yang digunakan dapat diduga mengikuti pola umum di Nusantara, yakni model halaqah yang kemudian dikenal dalam istilah pesantren dengan bandongan dan sorogan.

Eksistensi Masjid Al-Mujahidin sebagai masjid Kerajaan Bone, terus menjadi basis pendidikan Islam berupa pengajian Al-Qur'an dan kitab kuning (mangaji tudang) yang diselenggarakan oleh Kadi Bone dan para pembantunya. Seperti yang telah disebutkan sebelumnya bahwa beberapa orang Raja Bone yang didampingi Kadi Bone menjadi penganut sekaligus penyebar ajaran tarekat Khalwatiyah Yusufiyah. Bahkan ada yang dapat disebut ulama, karena menguasai bahasa Arab dan ilmu tarekat, serta menulis kitab, yakni La

\footnotetext{
${ }^{21}$ Lontara' Kerajang Soppeng milik Andi Palaloi no. 8 halaman 26 dan Lontara Kerajaan Soppeng milik Andi Rajeng Petta Lebbi, No. 20 halaman 23 dan 31, dalam Ali, Andi Muhammad. Bone Selayang Pandang. Cet. II; Watampone: Damai, 1986, h. 51-52.

${ }^{22}$ Lihat Asnawi Sulaiman, Sejarah Singkat Keqadhian (Qadhi) Bone, h. 14.
} 
Tenritappu Sultan Ahmad Shaleh Syamsuddin (1775-1812) yang didampingi oleh Arab Harun, Kadi Bone ke-8.

Arab Harun adalah seorang yang dipandang banyak berjasa dalam menyebar-kan ajaran Tarekat Khalwatiyah Yusufiyah di Kerajaan Bone. Hal ini dapat diketahui dari aktivitasnya sebagai penyalin risalah tarekat ini. Atas permintaan La Tenritappu ia menyalin banyak karya Syekh Yusuf dan muridnya, Syekh Abdul Dhahir atau Tuan Rappang I Bodi. Menurut catatan Abu Hamid bahwa sekitar 30 buah risalah yang pernah disalin oleh Arab Harun. Risalah-risalah tersebut adalah: (1) Fathu al-Rahman, (2) Matla' al-Saraair wa al-Zhawahir, (3) Mathalibu al-Salikin, (4) Fathu Kaifiyat al-Dzikri, (5) al-Barakat al-Sailaniyah, (6) al-Fawaaih al-Yusufiyat fi Bayaani al-Tahqiq, (7) Kaifiyat alManfai, (8) Tahshilu al-Inayah wa al-Hidayat, (9) Risalah Ghaayah al-Ikhtishaar wa al-Nihayah al-Intizdar, (10) Sirrul al-Asraar, (11) Daqaaiqul al-Asraar, (12) Bahjatu al-Tanwiyr, (13) Fassu Hikmat al-Ilahiyah, (14) al-A'yaanu al-Tsaabitah, (15) Tuhfat al-Mursalah, (16) Risalah al-Wudhuui, (17) Ma'rifah al-Tauhid, (18) Muqaddimah al-Fawaaid, (19) Asraaru al-Shalawaat, (20) Bahrun al-Lahut, (21), Wahdat al-Wujuud, (22) Al-Fautsu al-A'zdam, (23) Bayaan Allah, (24) Nuurul Haadiy Ila Thariiqy al-Rasyaad, (25) Bidaayatu al-Mubtadiy, (26) Tahkshishu alMa'aarif, (27) Daf'u al-Bala', (28) Ajaran Syekh Yusuf (Bahasa Bugis), (29) Futuhaatu al-Ilahiyyah, (30) Zubdatu al-Asraar. ${ }^{23}$

Karena ia adalah Kadi Bone, tentu saja aktifitas keilmuan Arab Harun lebih banyak dilakukan di Masjid Al-Mujahidin. Hal ini menjadikan Masjid AlMujahidin bukan hanya sebagai tempat pelaksaan ibadah-ibadah tertentu, seperti salat, melainkan sebagai basis utama pelaksanaan dan pengembangan pendidikan Islam di Kerajaan Bone. Kenyataan di atas juga menunjukkan bahwa materi pendidikan yang diajarkan oleh para Kadi Bone tidak terbatas pada dasar-dasar agama Islam, tetapi mencakup tasawuf.

Aktifitas pendidikan Islam di Masjid Al-Mujahidin semakin maju, ketika tahun 1809 M putra Arab Harun, Haji Pesona, tampil sebagai Kadi Bone ke-9 menggantikn ayahnya. Keilmuannya tidak diragukan, sebab ia pernah mengenyam pendidikan di Haramayn. Sebagai Kadi Bone, tentu saja tetap melanjutkan aktifitas keilmuan Kadi Bone sebelumnya, yang juga adalah ayahnya. Para masanya pendidikan Islam diduga kuat semakin berkembang, sebab di samping dia sendiri seorang ulama, ia diketahui didampingi seorang khatib (katte') yang dikenal sebagai ulama besar pada masanya, yakni Syekh Abu Bakar Palakka yang bergelar al-Khatib Bone. Sebelum menjadi khatib Bone, ia pernah mengenyam pendidikan di Mekah. Syekh Abu Bakar Palakka juga

\footnotetext{
${ }^{23}$ Naskah-naskah hasil salinan Arab Harun di atas saat ini tersimpan di Perpustakaan Nasional Jakarta No. A 108 (=C). Selesai disalin pada bulan Sya'ban 1221 H bertepatan dengan Oktober 1806 M). Lihat Abu Hamid, Syekh Yusuf: Seorang Ulama, Sufi dan Pejuang, h. 143. Bandingkan dengan Nabilah Lubis, Syekh Yusuf Al-Taj Al-Makassari; Menyingkap Intisari Segala Rahasia (Bandung: Mizan, 1996), h. 64.
} 
diketahui pernah menyalin beberapa risalah fikih maupun tasawuf (tarekat), baik ketika masih di Mekah maupun ketika kembali ke Bone dan menjabat sebagai khatib. Dia digelar al-Khatib Bone ${ }^{24}$

Berdasarkan catatan Wan Mohammad Shaghir Abdullah, diketahui bahwa al-Khatib Bone Abu Bakar Palakka setidaknya menyalin lima buah risalah, yakni:

1. Risalatul Wudhu, karya Tajuddin yang digelar dengan Tajul bin Arifin ibnu Sultan Utsman an-Naqsyabandi. Diselesaikan pada hari Sabtu, 26 Jumadil Awal di rumahnya di Palakka, tanpa menyebut tahun.

2. Al-Risalah an-Naqsyabandiyah, karya Syeikh Yusuf Tajul al-Khalwati Mankatsi. Dicatat pada halaman akhir, selesai penyalinan pada hari Sabtu, bulan Muharam, tanpa menyebut tahun. Pada salinan menggunakan nama "al-Faqir Khatib Bone", tanpa menyebut nama asli Haji Abu Bakar Bugis.

3. Jam'ul Fawaid as-Sunbuliyah al-Muwashshalah ila Maratibh al-'Aliyah karya gurunya, al-'Alim al-'Allamah al-'Arif ar-Rabbani Syeikh Muhammad As'ad bin Syeikh Muhammad Thahir as-Sunbul bin alAllamah Syeikh Muhammad Sa'id al-Makki.

4. Daqaiq al-Asrar fi Tahqiqi Qawa'id as-Sirriyah wa Bayani Ahlillahil Arifin, karya Syeikh Abul Fattah Abu Yahya Abdul Bashir ad-Dhariri, yaitu seorang murid Syeikh Yusuf Tajul Khalwati al-Mankatsi. Di akhir salinan dicatatkan, “...Khatib Bone di rumah di negeri Palakka, selesai menyalin pada waktu Dhuha, hari Rabu, 9 Zulkaiddah 1233 H".

5. Zubdah al-Asrar fi Tahqiqi Ba'dhi Masyarib al-Akhyar karya Syeikh Yusuf at-Tajul Khalwati al-Makassari. Dicatat selesai menyalinnya pada 9 Ramadan $1235 \mathrm{H}$ oleh Khatib Bone namanya Abu Bakar. ${ }^{25}$

Dari latar belakang keilmuannya (alumni Mekah) dan lima buah kitab yang disalin tersebut dapat dipastikan bahwa Syekh Abu Bakar Palakka adalah seorang ulama besar, sebagaimana ulama-ulama Nusantara alumni Haramayn. Sebagai Khatib di Kerajaan Bone yang mendampingi Haji Pesona (Kadi Bone) juga dapat diduga bahwa aktifitas keilmuannya dilaksanakan di Masjid AlMujahidin. Ilmu-ilmu yang diajarkannya juga dapat dipastikan merujuk pada ilmu fikih dan ilmu tarekat, seperti yang tertuang dalam beberapa kitab yang ia salin.

Pendidikan Islam yang berpusat di Masjid Al-Mujahidin kelihatannya terus berkembang ketika Kadi Bone dijabat oleh Kadi Bone ke-10, Syekh Ahmad (1823-1827 M) yang menggantikan Haji Pesona. Syekh Ahmad adalah adik

\footnotetext{
${ }^{24}$ Lihat http:/ulama. Blogspot.com/2005/09/Syeikh abu-bakar-palakka-html, kamis 27-9-2013.

${ }^{25}$ Lihat Wan Mohammad Shaghir Abdullah, Syekh Abu Bakar Palakka, dalam http:/ulama. Blogspot.com/200/09/Syeikh abu-bakar-palakka-html. Diakses pada Kamis 27-9-2013.
} 
Syekh Abu Bakar Palakka, Khatib Bone, seperti yang telah disinggung sebelumnya. Selama menjabat Kadi Bone mendampingi tiga Raja Bone; I Mani Arung Data, La Mappaseling, dan La Parenrengi. Sama dengan kakaknya, Syekh Ahmad juga dikenal sebagai seorang menganut tarekat Khalwatiyah Yusufiyah. Dalam Lontara' Akkarungeng ri Bone disebutkan bahwa ia menjadi guru tarekat bagi Raja Bone I Mani Arung Data. Ia juga diketahui menyalin salah satu kitab karya Syekh Yusuf al-Makassari, yakni Asrar ash-Shalah fi Tabyin Muqaranah an-Niyah bi Takbirah al-Ihram fi al-Fiqh wa at-Tashawuf 'ala I'tiqad Ahli asSunnah wa al-Jama'ah wa Mazhab as-Syafi'i. Selesai ditulis 25 bulan Haji, 1237 $\mathrm{H} /{ }^{26}$

Pada pertengahan abad ke-19, Kadi Bone dijabat oleh KH> Adam (18471865, w. 1865 M). Walaupun tidak ditemukan catatan khusus mengenai aktivitas pendidikan Islam yang dijalankan oleh KH. Adam, tetapi pengalamannya menimba ilmu di Mekah selama kurang lebih 8 tahun sebelum menjabat sebagai Kadi Bone, tentu menjadi pertimbangan kuat bahwa ia memiliki kedalaman dan keluasan ilmu-ilmu keislaman. Asnawi Sulaiman menyebutkan bahwa ketika KH. Adam menjabat sebagai Kadi Bone, ia merenovasi Masjid Al-Mujahidin dan untuk pertama kalinya mendirikan bangunan khusus kantor syara' di depan Masjid Al-Mujahidin. Bangunan bekas kantor syara' tersebut masih dapat disaksikan hingga hari ini. ${ }^{27}$

Selain itu, terdapat bukti yang dikatakan sebagai peninggalan KH. Adam yang hingga kini dapat disaksikan, yakni sebuah manuskrip kitab suci Al-Qur'an yang masih ditulis tangan. Pada lembaran akhir manuskrip Al-Qur'an ini terdapat keterangan bahwa "Al-Qur'an ini ditulis oleh al-Fakir Haji Abdussalam Al-Jawi Bugisi, pada tahun 1263 H." Didalamnya juga diterangkan bahwa ia (Haji Abdussalam) berasal dari Desa Pammana, sebuah desa yang terletak antara Wajo dan Bone. Al-Qur'an ini diperkirakan dibawa oleh KH. Adam dari Mekah, ketika ia kembali ke Bone setelah menyelesaikan pendidikannya. ${ }^{28}$ Walaupun manuskrip ini bukan karya $\mathrm{KH}$. Adam, namun peninggalan tersebut menjadi bukti bahwa ia adalah Kadi Bone yang mengajarkan Al-Qur'an di Masjid AlMujahidin.

Pada akhir abad ke-19 sampai awal abad ke-20, Kadi Bone dijabat oleh KH. Muhammad Yusuf atau Kadi Bone ke-11 (1879-1905 M). Ia adalah putra KH.

\footnotetext{
${ }^{26}$ Wan Mohammad Shaghir Abdullah, Syekh Abu Bakar Palakka, dalam http:/ulama. Blogspot.com/2005/09/Syeikh abu-bakar-palakka-html. Diakses pada Kamis 27-9-2013.

${ }^{27}$ Asnawi Sulaiman, Sejarah Singkat Keqadhian (Qadhi) Bone, h. 17.

${ }^{28}$ Manuskrip ini disimpan oleh Drs. Haji Muhammad Syata (umur 92 tahun). Ia adalah keturunan ke-4 dari KH. Adam. Ia menjelaskan bahwa manuskrip ini diperoleh dari ayahnya, KH. Yunus bin Abd. Rasyid, Imam Macege, dari neneknya. Neneknya atau ibu dari KH. Yunus bin Abdul Rasyid adalah putri dari KH. Adam. Drs. Haji Muhammad Syata, Wawancara, Watampone 20 November 2013. Deskripsi singkat manuskrip tersebut adalah; panjang $50,6 \mathrm{~cm}$ dan lebar $20 \mathrm{~cm}$. Tulisannya masih cukup jelas hingga masih dapat dibaca dengan jelas. Pada lembaran pembuka, yakni lembar Surat AlFatihah dan awal Surat Al-Baqarah terdapat hiasan berupa lukisan bunga paduan dua warna, merah dan hitam. Hiasan yang sama juga terdapat pada lebar pertengahan dan penutup.
} 
Adam. Seperti ayah dan beberapa pendahulunya, KH. Muhammad Yusuf juga pernah menempuh pendidikan di Mekah selama empat tahun. ${ }^{29}$ Oleh karena itu, patut diduga bahwa KH. Muhammad Yusuf melanjutkan pengajian Al-Qur'an dan kitab kuning (mangaji tudang) di Masjid Al-Mujahidin. Terkait dengan hal ini, terdapat keterangan Abdul Rahman Getteng bahwa pesantren yang berdiri pertama kali di Sulawesi Selatan adalah di Watampone. Pesantren ini didirikan oleh Petta Yusuf, seorang ulama yang pernah menimba ilmu di Mekah. ${ }^{30}$

Peneliti telah berusaha mencari data tentang Petta Yusuf yang mendirikan pesantren di Watampone tersebut, namun sama sekali tidak diperoleh keterangan selain bahwa pada masa lalu ulama yang mengadakan pengajian kitab kuning atau mangaji kitta di Watampone bernama Petta Yusuf adalah Petta Kali Yusuf atau Kadi Bone KH. Muhammad Yusuf yang membina pengajian kitab di Masjid Al-Mujahidin. Oleh karena itu, peneliti menduga kuat bahwa Petta Yusuf yang disebut Abd. Rahman Getteng tersebut adalah Kadi Bone ke-11 KH. Muhammad Yusuf yang oleh masyarakat Bone mengenalnya sebagai Petta Kalie Yusuf. Kemudian pesantren yang didirikan itu dapat dipastikan berupa pengajian kitab kuning atau mangaji kitta yang dilaksanakan di Masjid Al-Mujahidin Watampone.

Pada masa jabatan KH. Abdul Hamid, Kerajaan Bone kedatangan seorang ulama dari Mekah, yakni Syekh Mahmud Abdul Jawad. ${ }^{31}$ Pada awal kedatangannya, ia mengadakan pengajian kitab di Masjid Al-Mujahidin atas dukungan Raja Bone La Mappanyukki Sultan Ibrahim dan Kadi Bone KH. Abdul Hamid. Dari pengajian inilah, kemudian pada tahun pada tahun 1933 -atas prakarsa Raja dan Kadi Bone tersebut didirikan Madrasah Amiriyah Islamiyah di Watampone. ${ }^{32}$ Ketika Raja Bone terakhir (ke-33) La Pa'benteng naik tahta, bersamaan itu pula diangkat KH. Sulaiman sebagai Kadi Bone ke-18 menggantikan KH. Abdul Hamid. Ia pun tetap melanjutkan pengajian di Masjid Al-Mujahidin.

Pada masa KH. Muhammad Rafi Sulaiman menjabat sebagai Kadi Bone, yakni mulai tahun 1962 sampai 1991, di Masjid Al-Mujahidin pendidikan Islam terus berjalan. Bahkan dalam bentuk yang lebih terorganisir, yakni berupa madrasah diniyah. Masyarakat Bone menyebutnya dengan istilah Sekola Ara'. Beberapa orang kiai turut membantu di antaranya adalah KH. Rahman Lalo dan KH. Khatib Taslim. Bahkan sampai era tahun 2000-an di Masjid Al-Mujahidin masih diselenggarakan halaqah pengajian kitab kuning setiap selesai salat

\footnotetext{
${ }^{29}$ Lihat Asnawi Sulaiman, Sejarah Singkat Keqadhian (Qadhi) Bone, h. 18.

${ }^{30}$ Lihat Abd. Rahman Getteng, Pendidikan Islam di Sulawesi Selatan; Tinjauan Historis dari Tradisi Hingga Modern, h. 77-78 .

31 Lihat Ridhwan, Pendidikan Islam di Bone: Studi Tentang Peran Kadi dalam Pengembangan Pendidikan Islam, (Lhoksemawe Aceh: Unimal Press, 2016), h. 94

${ }^{32}$ Haji Lihat Ridhwan, Pendidikan Islam di Bone: Studi Tentang Peran Kadi dalam Pengembangan Pendidikan Islam, $h .94$
} 
magrib yang dibina oleh KH. Rusyaid Mattu, mantan Dekan Fakultas Syari'ah IAIN Alauddin Watampone. ${ }^{33}$

Seperti yang disaksikan oleh peneliti sendiri, bahwa di Masjid AlMujahidin hingga saat ini masih berjalan pengajian dasar Al-Qur'an berupa TK/TPA. Kemudian pada sore hari diselenggarakan pendidikan Islam dalam bentuk Madrasah Diniyah. Namun demikian, sangat disayangkan bahwa pengajian kitab kuning atau mangaji kitta, sudah tidak ada lagi.

\section{Simpulan}

Masjid Tua Almujahidin Watampone Kabupaten Bone, Hasil penelitian menunjukkan bahwa Masjid Tua Almujahidin didirikan oleh Fakih Amrullah sekitar tahun 1632 Masehi. Ia adalah Kadhi pertma di Kerajaan Bone. Pembangunan Masjid Almujahidin diperuntukkan kepada keluarga kerajaan Bone, sekaligus sebagai tempat pelaksanaan dan pembinaan pendidikan Islam. Sebelum kerajaan Bone berintegrasi dengan Negara Kesatuan Indonesia, Para Kadhi Kerajaan Bone menjadikan Masjid Tua Almujahidin sebagai tempat aktifitas mereka. Fungsinya sebagai tempat pendidikan terus berlanjut, walaupun Bone tidak lagi sebagai Kerajaan.

\section{Referensi}

John Renard "All The King's Falcon; Rumi On Prophets and Revelation", diterjemahkan oleh Muhammad Hasyim Assagaf, Rajali Sang Raja; Senandung Rumi Tentang Nabi dan Wahyu. Cetakan pertama; Jakarta: PT. Serambi Ilmu Semesta, 2001.

Karena Amstrong "Muhammad; A Biografi of Prophet" diterjemahkan oleh Sirikit Syah, Muhammad Sang Nabi; Sebuah Biografi Kritis. Cetakan pertama; Surabaya: Risalah Gusti, 2001.

Zuhairi Misrawi. Mekkah; Kota Suci, Kekuasaan, dan Teladan Ibrahim. Jakarta: PT. Media Kompas Nusantara, 2009.

Nurcholish Madjid, Pintu-Pintu Menuju Tuhan. Cetakan IV; Jakarta: Paramadina, 2002.

Umar Amin Hoesin, Kultur Isla. Jakarta: Bulan Bintang. 1982.

Lapidus, "A History of Islamic Socienties" diterjemahkan oleh Ghufron A. Mas'adi, Sejarah Sosial Umat Islam, Jilid I dan II. Cet. I; Jakarta: RajaGrafindo Persada, 1999.

\footnotetext{
${ }^{33}$ Lihat Ridhwan, Pendidikan Islam di Bone: Studi Tentang Peran Kadi dalam Pengembangan Pendidikan Islam), h. 98
} 
Trias Kuncahyono, Jerussalem; Kesucian, Konflik, dan Pengadilan Terakhir. Cetakan pertama; Jakarta: PT. Media Kompas Nusantara, 2008.

Azsyumardi Azra, Pendidikan Islam; Tradisi dan Modernisasi Menuju Melinium Baru. Cetakan I; Jakarta: PT Logos Wacana Ilmu, 1999.

George Abraham Makdisi "The Rise of Humanism in Classical Islam and The Christian West" diterjemahkan ke dalam bahasa Indonesia oleh A. Syamsurizal dan Nurhidayah, Cita Humanisme Islam; Panorama Kebangkitan Intelektual dan Budaya Islam dan Pengaruhnya Terhadap Renaissance Barat. Jakarta: PT. Serambi Ilmu Semesta, 2007.

G.F. Pijper "Studien over de geschiedenis van de Islam in Indonesia 1900-1950", diterjemahkan oleh Tudjimah dan Yessi Augustin, Beberapa Studi Tentang Sejarah Islam di Indonesia 1900-1950. Cet Kedua; Jakarta: UIPress, 1986.

Asnawi Sulaiman, Sejarah Singkat Keqadhian (Qadhi) Bone (Cetakan I; Jakarta: Lembaga Solidaritas Islam al-Qashash, 2004

http://www.tribun-timur.com/read/artikel/49050 Cetak Panrita Dari Bontoala, Salemo, Hingga Mangkoso, Kamis, 17 September 2009 | 15:58 WITA, diakses pada tanggal 5 Juni 2012.

Leonard Y. Andaya, Warisan Arung Palakka; Sejarah Sulawesi Selatan Abad ke-17, Cetakan II Edisi Indonesia; Makassar: Ininnawa, 2006.

Mattulada, LATOA: Satu Lukisan Analitis Terhadap Antropologi Politik Orang Bugis, h. 76.

Andi Zainal Abidin Farid, Persepsi Orang Bugis Makssar Tentang Hukum Negara dan Dunia Luar, h. 36.

Hamid, Abu. Syekh Yusuf; Seorang Ulama, Sufi dan Pejuang. Edisi Kedua; Jakarta: Yayasan Obor Indoenesia, 2005.

Nabilah Lubis, Syekh Yusuf Al-Taj Al-Makassari; Menyingkap Intisari Segala Rahasia . Bandung: Mizan, 1996.

http:/ulama. Blogspot.com/2005/09/Syeikh abu-bakar-palakka-html, kamis 279-2013.

Wan Mohammad Shaghir Abdullah, Syekh Abu Bakar Palakka, dalam http:/ulama. Blogspot.com/200/09/Syeikh abu-bakar-palakka-html. Diakses pada Kamis 27-9-2013.

Getteng, Abd. Rahman. Pendidikan Islam di Sulawesi Selatan; Tinjauan Historis dari Tradisi Hingga Moder., Cetakan Pertama; Yogyakarta: Graha Guru, 2005. 
Ridhwan, Pendidikan Islam di Bone: Studi Tentang Peran Kadi dalam Pengembangan Pendidikan Islam, Lhoksemawe Aceh: Unimal Press, 2016.

Zuhairi Misrawi, Madinah; Kota Suci, Piagam Madinah, dan Teladan Muhammad Saw. Jakarta: PT. Kompas Media Nusantara, 2009. 